\title{
SYNOPTIC CONDITIONS GENERATING IMPORTANT SNOWFALLS AND THEIR RELATION WITH AVALANCHES IN 2015-2016 WINTER
}

\author{
C. GRECU ${ }^{1}$, A. PAŞOL ${ }^{1}$, Narcisa MILIAN ${ }^{1}$, U. RECKERTH ${ }^{1}$
}

\begin{abstract}
The paper presents and analyzes variations in weather conditions, meteorological and nivological (snow related) parameters that favored avalanches triggering in Bucegi and Făgăraş Mountains during 2015-2016 winter, an area monitored by the program for snow and avalanches within Romanian National Meteorological Administration. Analyzed parameters are measured on daily observations and weekly measurements, at Bâlea-Lac, Vârful Omu, Sinaia and Predeal meteorological stations and during the campaigns of measurements made within project Snowball, which aims to inventory cases of avalanches previously known in our country and the favorable conditions, for a better avalanche risk estimation and to reduce their effects on the environment and people. Data from daily observations and NCEP reanalysis ground level pressure maps, absolute topography and temperature maps at $500 \mathrm{hPa}$ were used, from http://www.wetter3.de.
\end{abstract}

Keywords: avalanche, sea-level pressure, temperature, snowfall

\section{INTRODUCTION}

The purpose of this paper is to investigate the precursory conditions of the atmosphere and snow layer for the recorded avalanches during 2015-2016 winter and to complete the inventory cases of avalanches in our country. The study is part of Snowball Project and was made for almost every last year (Milian N. et all, 2011, 2014, 2015, 2016; Voiculescu M. et all, 2010; Munteanu A. et all, 2013). Results will help for a better understanding of the phenomena and thus a better avalanche risk estimation, in order to reduce their effects on the environment and people. Variations in synoptic-scale atmospheric circulation affect the evolution of snowpack characteristics, wich in turn affect spatial patterns of avalanche activity (Ferguson et al, 1990; Fitzharris 1981,1987).

First snowfall of 2015-2016 winter season was reported on high altitudes in October 13 in Bucegi Mountains and October 21 in Făgăraş, but with no continuous snow layer. A new, temporary snowfall was recorded on November 16, but only after November 24 a continuous snow layer was formed in most mountain areas, as measurements at Bâlea-Lac, Sinaia, Predeal and Vârful Omu meteorological stations showed. Snow layer was continuous at Bâlea-Lac and Vârful Omu up to June 04, respectively 20, 2016. Simultaneously, snow layer had

\footnotetext{
1 SRPV Sibiu, CMR Transilvania-Sud, 550003 Sibiu, Romania, e-mail: narcisa.milian@gmail.com
} 
been continuous at all mountain stations between November 25, 2015 and February 23, 2016. During this winter, there were 41 records on avalanches and snow flows observed in the field, over 39 days, in all the mountains ranges in the country, including the monitored ones.

Temperatures were generally above the norm and during most of the months, precipitation and snowfall amount were lower than the climatological average. At the end of the season, snowmelt has been accelerated (in one week, at Vârful Omu meteorlogical station, snow amount decreased from $100 \mathrm{~cm}$ to a discontinuous layer).

There have been several heavy snowfalls episodes, with large amounts of snow, thus increasing the risk of avalanche triggering. Over $20 \mathrm{~cm}$ new snow felt during three snowfall episodes in the Făgăraş Mountains, at Bâlea-Lac $(61 \mathrm{~cm}$ between January 21-22, 2016; $23 \mathrm{~cm}$ between March 09-10,2016; $50 \mathrm{~cm}$ between May 03-05,2016) and during two episodes in Bucegi, at Vârful Omu (27 cm March 09-10,2016; 49 cm - May 03-05,2016).

With GELINIV software (Météo France), used in operational activity, annual schedule of daily meteorological parameters observed at the four meteorological stations can be seen. It shows the variation of snow thickness, maximum and minimum temperature, wind speed and amount of daily precipitation. Important snowfall and alternation of colder with warmer periods that favored partial snow melting and surface wettness can be easily seen on Fig.1.

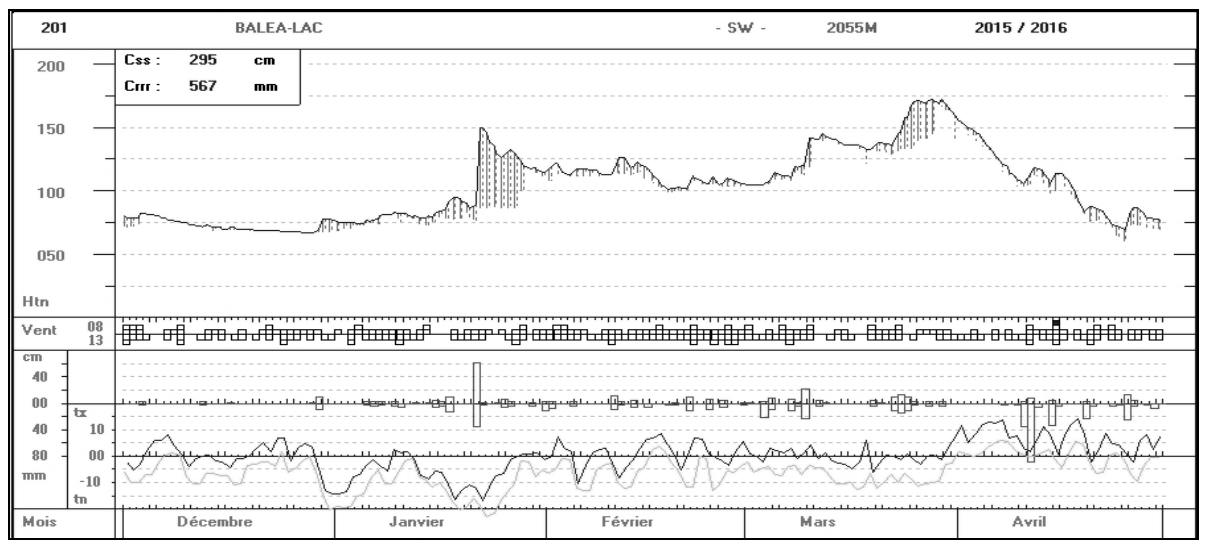

Fig. 1. 2015-2016 winter season - daily meteorological parameters measured at Bâlea-Lac meteorological station - GELINIV software (Météo France)

\section{DATA AND METHODS}

The methodology consist in identifying the periods with recorded avalanches and analyzing the synoptic conditions which could have influenced the stability of the snow pack. Some influences are obvious, like heating during spring, which determines the humidification of the snow layer and release of wet 
avalanches. In this paper, we analyze ground pressure, $500 \mathrm{hPa}$ geopotential and wind, $850 \mathrm{hPa}$ temperature and thickness of the snow layer, as factors that determine snow pack behavior.

The primary data set used in this study consists of daily observed avalanche data and weather data (Castebrunet $\mathrm{H}, 2012$ ) from the massifs where operational avalanche forecasting is done (Bucegi and Făgăraş). Avalanche observations are also taken from local mountain rescue teams. The majority of these avalanche observations can be accessed online in the Annual Report (***, Bilanţul nivologic). For meteorological analyses, we have used the NCEP/NCAR Reanalysis Project maps, available online (www.wetter3.de/archive). For each analyzed period, sealevel pressure, $500 \mathrm{hPa}$ geopotential height and wind maps, $850 \mathrm{hPa}$ temperature maps have been manually classified into a synoptic type based on patterns of high and low elevation geopotential heights over Romania. Hourly data and daily precipitation data from the meteorological weather stations of Bucegi and Făgăraş Mountains were used to characterize local weather (***, Baza de date).

\section{ANALYSIS OF THE PHENOMENA}

As recorded in the Annual Report (***, Bilanţul nivologic), during the studied winter season, there have been 41 days with reported avalanches in all mountain areas, most of them in Bucegi and Făgăraş, where the National Meteorological Administration program for snow and avalanches is running.

Of these, 16 occurred on high pressure conditions (ground pressure above $1020 \mathrm{mb}$ ), from wich 7 greater than $1030 \mathrm{mb}$. The Azores Ridge acted in 14 cases, the East European Anticyclone in 5 cases, and in 1 case an anticyclone zone formed by the two Highs. A contact between Azores High and Icelandic Low was recorded in 12 cases (1015 to $1020 \mathrm{mb}$ ). Pressure at ground level was lower than $1015 \mathrm{mb}$ in 13 cases, due to the Icelandic Low, with his Trough extended to southern Europe (7 cases), cyclones formed in the Mediterranean (6 cases).

At the level of $500 \mathrm{hPa}$, geopotential values ranged from 546 to $586 \mathrm{dmgp}$, greater than a year before ( 520 to $576 \mathrm{hPa}$ ). Of these, in 3 cases the values were between 540 and 550 dmgp, 7 between 550 and 560 dmgp, 18 between 560 and 570 dmgp, 8 between 570 and 580 dmgp and 5 over $580 \mathrm{hPa}$. The most common height structure was the associated Azores Ridge, with 25 cases. In 2 cases, over our country was the ascendent part of the Trough (with a southwestern circulation), and in 14 cases the associated Icelandic Low trough.

Wind direction at $500 \mathrm{hPa}$ was from north in 2 cases, south in 2 cases, south-west in 12 cases, west in 10 cases and north-west in 15 cases. As regarding wind intensity, in 9 cases it was strong, 18 - moderate and in other 14 it was slow.

The values of the $850 \mathrm{hPa}$ level isotherm were between -10 and -5 degrees in 1 case, between -5 and -1 degree in 4 cases, -1 to 1 degree in 5 cases; 1 to 5 degrees in 10 cases; 5 to 10 degrees in 12 cases; 10 to 15 degrees in 8 cases and more than 15 degrees in 1 case. 


\section{SYNOPTIC CONDITIONS FOR IMPORTANT SNOWFALLS}

\subsection{January 18 to 25,2016}

During this period, one heavy snowfall has been recorded, with $62 \mathrm{~cm}$ fresh snow at Bâlea-Lac meteorological station. On January 18, 2016, Romania was influenced by a contact between the Azores High to the west of the country and the Icelandic Low, with several cyclonic cores on east, and on higher levels (at $500 \mathrm{hPa}$ ) an Icelandic through characterized by a very cold air mass (of -35 degrees). Between 19 and 21 January, an anticyclonic field was present on the ground and at $500 \mathrm{hPa}$, associated with a cold air mass. During this period, the weather was cold, with frosty nights and isolated, weak snowfall (Fig.2).

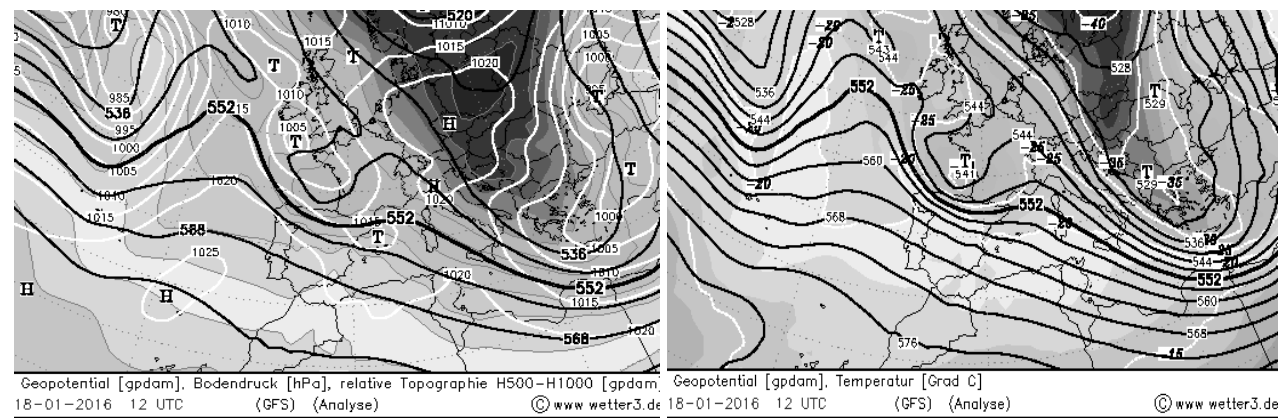

Fig. 2. NCEP numerical model - reanalysis: Ground-level pressure, relative topography, 500hPa geopotential and temperature on 2016.01.18, 12 UTC, (www.wetter3.de)

Between 21 and 22 January, ground pressure continued to rise, and an anticyclonic high, with values over $1030 \mathrm{mb}$, was stationary over the country. At $500 \mathrm{hPa}$ level, the cold northern through (-40 degrees) continued to move down to south, bringing significant snow amounts $(35 \mathrm{l} / \mathrm{m}$ at Bâlea-Lac station, with $62 \mathrm{~cm}$ of fresh snow) (Fig.3).
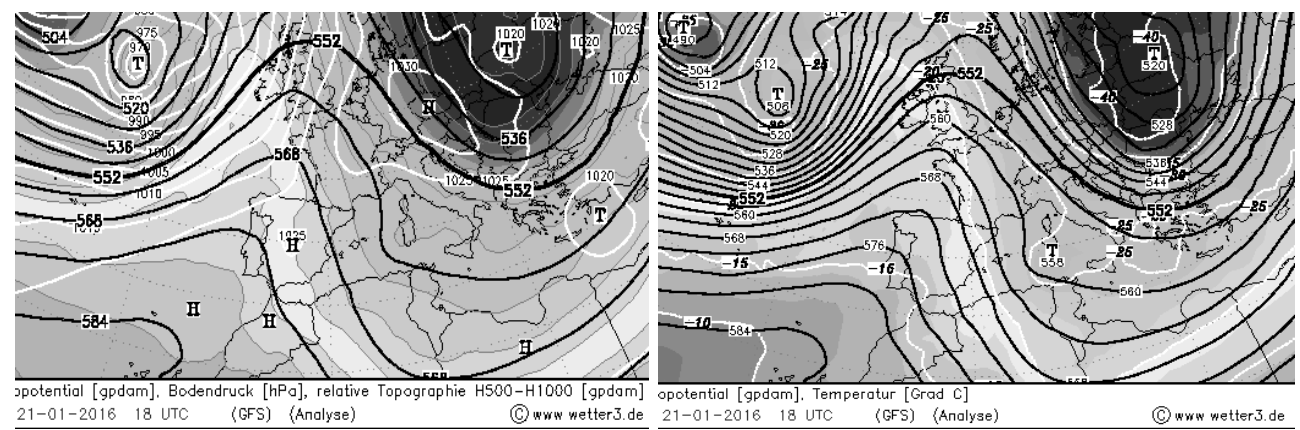

21-01-2016 18 UTC (GFS) (Analyse)

(C) www wetter3.de

opotential (gpdam]. Timperatur Grad C]
$21-01-2016$ 18 UTC (GF) (Analyse)

(C) www wetter 3.de

Fig. 3. NCEP numerical model - reanalysis: Ground-level pressure, relative topography, 500hPa geopotential and temperature on 2016.01.21, 18 UTC, (www.wetter3.de)

Between January 22 and 23, the barometric maximum of $1035 \mathrm{mb}$ was maintained at the ground, and in the altitude, at 500 hpa level, the descendent part of the Icelandic Trough with a cold mass of -35 degrees, has generated local, weak, snowfalls. Snow cover has slightly decreased at Bâlea-Lac. Between January 21 to 
25 , a meteorological warning was issued, regarding very low temperatures and frost, especially during nights and mornings.

Due to the snowfalls, avalanches falled on January 24 in Făgăraş Mountains. Several avalanches happened later, between February 16 to 18, on both Bucegi and Făgăraş Mountains.

\subsection{March 6 to 12, 2016}

Between March 6 to 8, the weather was very hot and became unstable towards the end, with moderate precipitations $(12 \mathrm{l} / \mathrm{m})$ in the mountains. These changes occurred while Icelandic through move from west, due to the cyclonic core over Transylvania and the afferent frontal system (Fig.4). The upward side of the trough favored intense southern winds. Snow increased by $7 \mathrm{~cm}$ at Bâlea-Lac.
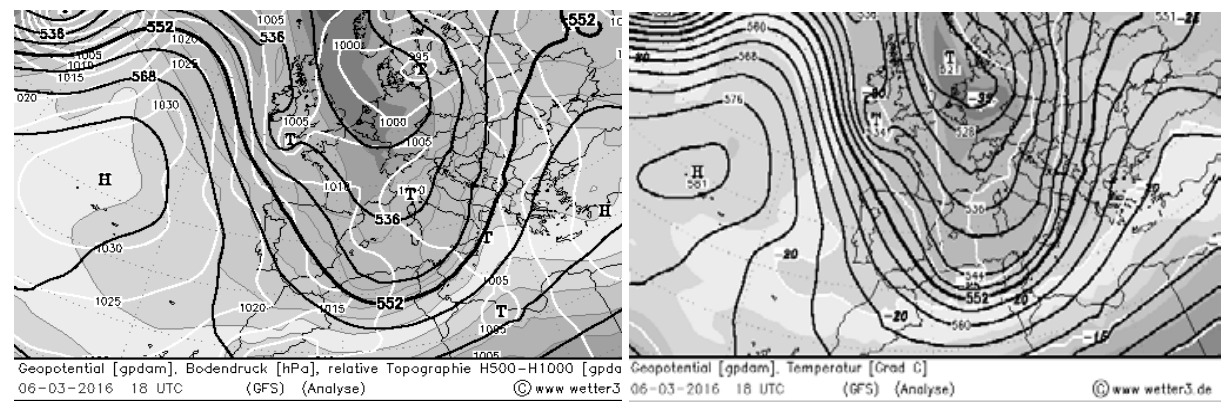

Fig. 4. NCEP numerical model - reanalysis: Ground-level pressure, relative topography, 500hPa geopotential and temperature on 2016.03.06, 18 UTC, , (www.wetter3.de)

Between March 8 to 10, the weather has cooled down and was generally unstable, with large amounts of precipitations, while snow cover grew by $23 \mathrm{~cm}$ at Bâlea-Lac and $27 \mathrm{~cm}$ at Vârful Omu. During this period, our country was in an area of contact between the Icelandic Trough positioned in west and Eastern European High at north-east of the country (Fig.5).

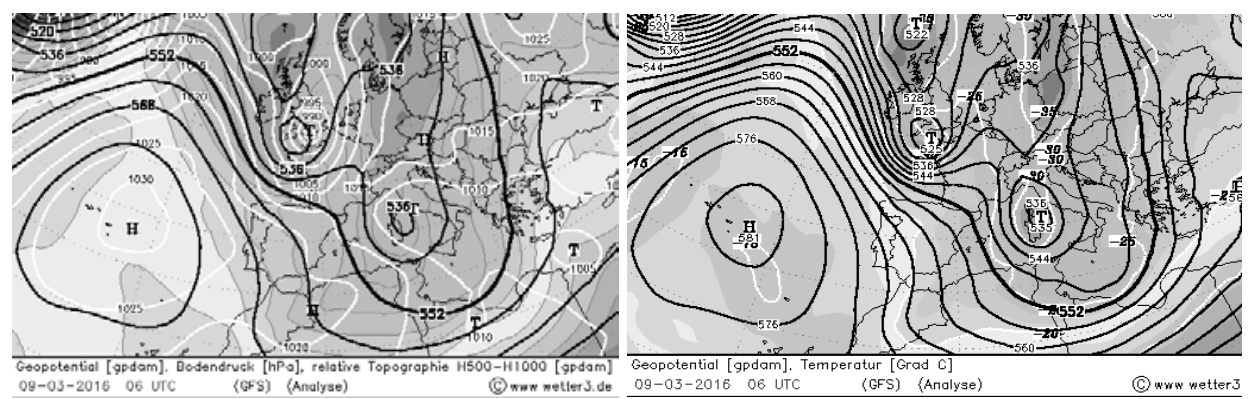

Fig. 5. NCEP numerical model - reanalysis: Ground-level pressure, relative topography, 500hPa geopotential and temperature on 2016.03.09, 06 UTC, (www.wetter3.de)

During March 10 and 12, weather continued to cool down and weak precipitations has occurred. Icelandic through remained on altitude, and at the ground level, there was a contact area between an anticyclonic belt positioned at 
the north of the country and the depressionary field, filled with Mediterranean cyclones in southern and southeast Romania. Snow layer grew was very weak (Fig.6). For March 09 and 11, a new meteorological warning was issued for large amounts of precipitations and strong winds, including Făgăraş Mountains.

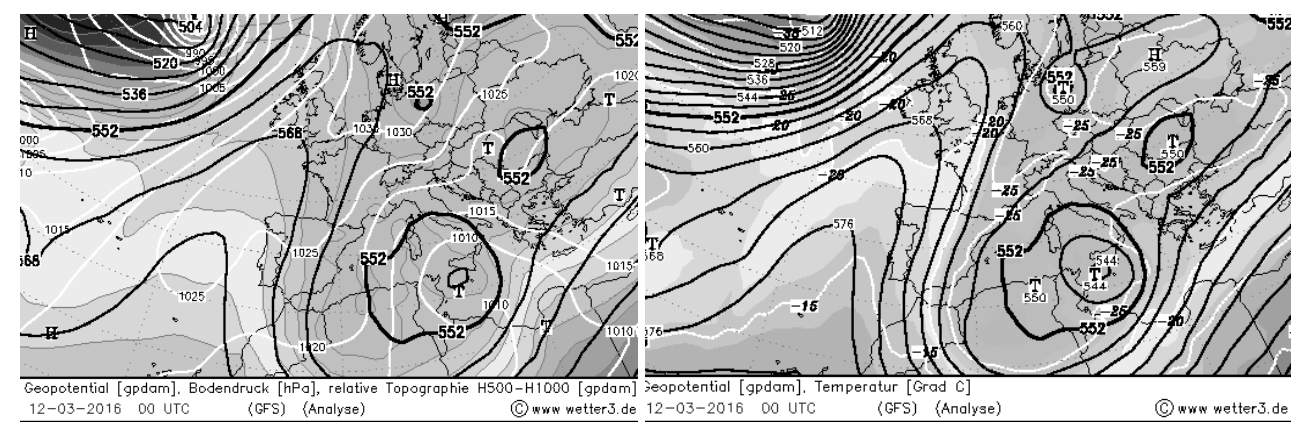

Fig. 6. NCEP numerical model - reanalysis: Ground-level pressure, relative topography, 500hPa geopotential and temperature on 2016.03.12, 00 UTC, (www.wetter3.de)

After the snowfalls, on March 10, avalanches were recorded in Făgăraş Mountains, followed by several avalanches between March 26 and April 3, in Bucegi, Făgăraş, Parâng and Retezat Mountains.

\subsection{May 01 to 06, 2016}

The first two days of May 2016 started with warm and beautiful weather. A warm advection was induced by a southern flow generated by the preexisting warm ridge retreating in the front of the advancing Icelandic Trough, which has developed a Mediterranean core cyclone on it's way to the Black Sea. At the ground, the Azores High has retired, being replaced by a Mediterranean cyclonic field (Fig.7).
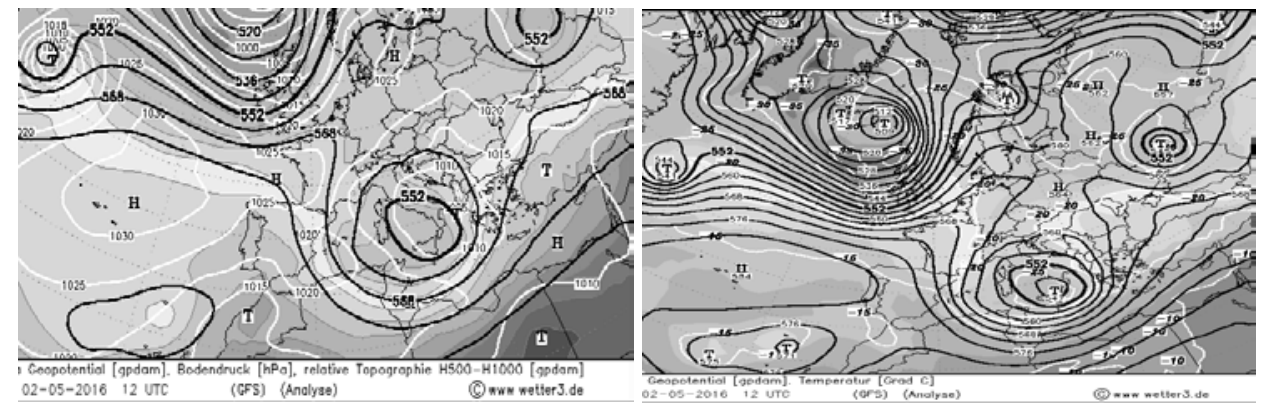

Fig. 7. NCEP numerical model - reanalysis: Ground-level pressure, relative topography, 500hPa geopotential and temperature on 2016.05.02, 12 UTC, (www.wetter3.de)

On May 03 and 04, the weather got colder and unstable, with large amounts of precipitations (20 and 26 1/sqm respectively at Bâlea-Lac). Along with the movement of the Mediterranean cyclone and the associated frontal system across southern Romania to the Black Sea, the airflow has changed from north-east to south-west, while the Carpathians orographicaly amplyfied rainfall quantities. In these two days, snow has 
increased $50 \mathrm{~cm}$ at Bâlea-Lac and $49 \mathrm{~cm}$ at Vârful Omu, while a meteorological warning was issued for large amounts of precipitations and strong winds (Fig.8).
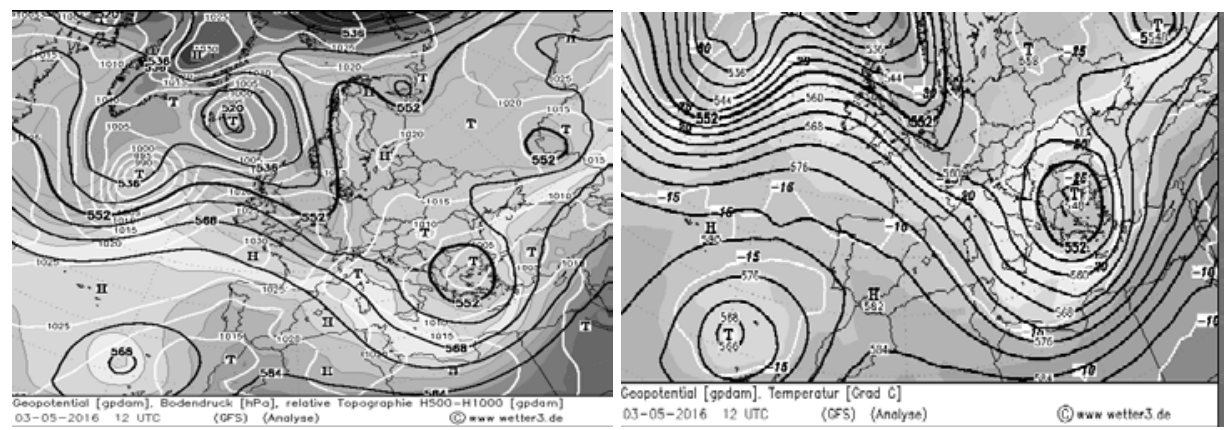

Fig. 8. NCEP numerical model - reanalysis: Ground-level pressure, relative topography, 500hPa geopotential and temperature on 2016.05.03, 12 UTC, (www.wetter3.de)

Between May 05 and 06, under the influence of the Mediterranean cyclone positioned over the Black Sea and Azores Ridge advancing from north-west, weather remained unstable, with a predominantly northern air circulation. The precipitations falled on extensive areas, but they were weaker than previous days. Temperatures rised and snow amount slightly decreased (Fig.9).

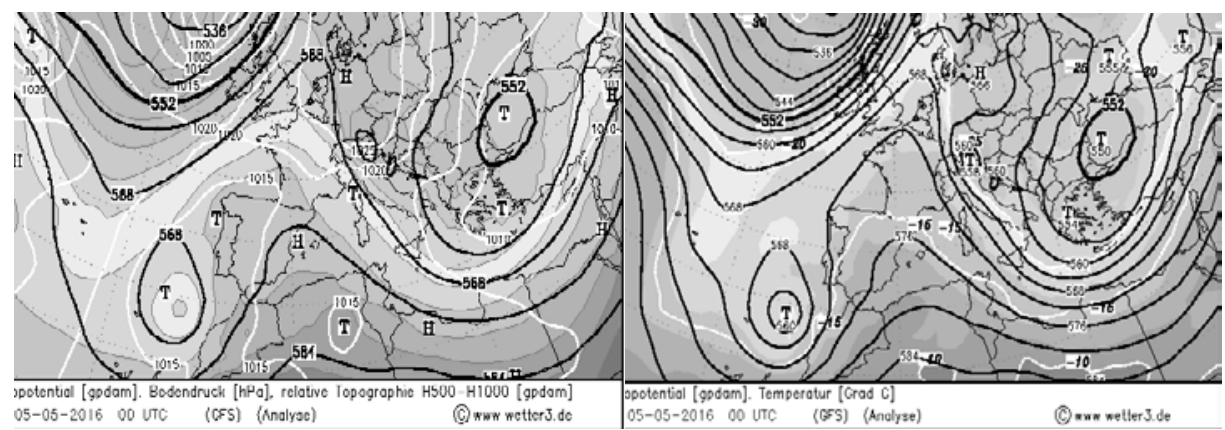

Fig. 9. NCEP numerical model - reanalysis: Ground-level pressure, relative topography, 500hPa geopotential and temperature on 2016.05.05, 00 UTC

Two avalanches were recorded on May 1, then, after the snowfalls, between May 11 and 22, several avalanches in Făgăraş and Bucegi Mountains.

\section{CONCLUSIONS}

Favorable conditions for avalanches triggering occurred on different synoptic context and over all winter season. Usually, a low pressure system at ground levels, often associated with a trough in higher altitudes, is responsible for heavy snowfalls. Most of the times, a deep low associated with heavy snowfalls is passing over Romania in 1-3 days, (sometimes longer, due to a stationary or retrograde activity influenced by an atmospheric jam) and is usually followed the next days by a high pressures system, according to the general circulation of the 
atmosphere over middle European latitudes. A high pressure system is often associated with sunny days in the mountains. As most of the avalanches happened on high sea-level pressure, with associated height structures, we can conclude that, for the 2015-2016 winter, avalanches happened most because of high thermal values and transformations that occur within the snow, leading to unstable structures and less in case of significant snowfall.

Acknowledgements: The research leading to these results has received funding from EEA Financial Mecanism 2009 - 2014 under the project contract no 19SEE/2014.

\section{REFERENCES}

1. ***, Bilanţul nivologic al sezonului de iarnă - publicaţie anuală, incepând din 2004, Administraţia Naţională de Meteorologie, București;

2. ***, Baza de date, Administraţia Naţională de Meteorologie, Bucureşti;

3. http://www.wetter3.de, archive accessed on December 10-20, 2016;

4. Casterbrunet H. et all, (2012), Snow and weather climatic control on snow avalanche occurrence fluctuations over 50yr in the French Alps, Clim. Past, 8, 855-875

5. Ferguson S. A. et al, (1990), Avalanche weather forecasting at the Northwest Avalanche Center, Seattle, Washington, U.S.A. J. Glaciol.,36, 57-66.;

6. Fitzharris B.B, (1987), A climatology of major avalanche winters in Western Canada, , Atmosphere-Ocean, 25: 2, 115-136;

7. Jaedicke C, Bakkehøi S, (2007), Climate database for avalanche consulting and warning in Norway, Cold Regions Science and Technology, 47, 1-2, 171-179

8. Milian N., Stăncescu M., (2011), Contextul nivometeorologic al riscului mare şi foarte mare de avalanşă din iarna 2010-2011, Sesiunea anuală de Comunicări Ştiinţifice a ANM;

9. Milian N., (2014), High and very high avalanche risk during 2012-2013 winter season, in the mountain area covered by nivological program, Conferinţa Aerul şi Apa Componente ale Mediului, 23-24.03.2014, Cluj-Napoca, 330-337

10. Milian N., Grigore I.G., (2014), Manifestări de vreme extremă. Avalanşele din cursul iernii 2013-2014, Sesiunea anuală de Comunicări Ştiinţifice a ANM;

11. Milian N., (2015), Synoptic Conditions for Avalanche Cases in Romania, Conferința Aerul şi Apa Componente ale Mediului, Cluj-Napoca, 299-306;

12. Milian N. et al, (2015), Variaţiile parametrilor nivometeorologici în cursul iernii 2014-2015, Sesiunea anuală de Comunicări Ştiinţifice a ANM;

13. Milian N., Paşol A., (2016), Synoptic Avalanche Triggering Conditions during 20142015 Winter; Conferinţa Aerul şi Apa Componente ale Mediului, Cluj-Napoca;

14. Munteanu A. et all, (2013), The Snow Condition, The Avalanches Caused and the Dynamic of the Avalanches Corridors During the Winter 2007-2008. Case Study, Padinile Frumoase (Piatra Craiului Mountains, Romania); Revista Riscuri şi Catastrofe Nr 12, Volumul XII, nr. 1/2013, Cluj, 157-173;

15. Voiculescu M. Et all, (2010), Analysis of Snow Avalanche from Mars 07, 2007 within the Călțun-Negoiu Area, in the Făgăraş Massif (Southern Carpathians), Analele Universităţii din Oradea, Seria Geografie, Tom XX, no. 1/2010, 22-33. 